\title{
O RAIO X DO JAIR BOLSONARO*
}

GABRIELA M. PACHECO DÁVILA**

Universidade Federal do Rio Grande do Sul (UFRGS) gabrielapd1@gmail.com

Recibido: 12/12/2020 Aceptado: 26/02/2021

doi: https://doi.org/10.26439/contratexto2021.n035.5022

RESUMO. Esse artigo tem como objetivo apresentar as singularidades e irregularidades mais representativas do ex-candidato e atual presidente, Jair Bolsonaro, em vídeos de divulgação emitidos durante a campanha presidencial de 2018 focado no uso da linguagem corporal. Através da metodologia qualitativa com procedimento na análise de imagens e vídeos com inspiração em conceitos da semiótica da cultura. A análise permitiu entender que em época eleitoral a linguagem corporal é relevante já que é um tempo em que os candidatos são mais simpáticos, permitindo que os limites espaciais sejam reduzidos, além de discursos agressivos e adereços estranhos que conformam a semiosfera da campanha eleitoral.

PALAVRAS-CHAVE: Jair Bolsonaro / linguagem corporal / semiótica da cultura / corpo eleitoral / comunicação

\section{EL RAYO X DE JAIR BOLSONARO}

RESUMEN. Este artículo tiene como objetivo presentar las singularidades e irregularidades más representativas del excandidato y actual presidente Jair Bolsonaro en videos publicitarios difundidos durante la campaña presidencial de 2018 centrados en el uso del lenguaje corporal. Mediante la metodología cualitativa con procedimiento en el análisis de imágenes y videos con inspiración en conceptos de semiótica de la cultura. El análisis permitió comprender que el lenguaje corporal es relevante en el período electoral, ya que es un momento en el que los candidatos son más solidarios, lo

\footnotetext{
*Uma versão do texto foi apresentada na Intercom 2020.

** Mestre em Comunicação e informação pela Universidade Federal do Rio Grande do Sul, Brasil. (véase: http://orcid.org/0000-0001-6190-5960)
} 
que permite reducir los límites espaciales, además de discursos agresivos y extraños accesorios que conforman la semiosfera de la campaña electoral.

PALABRAS CLAVE: Jair Bolsonaro / lenguaje corporal / cuerpo electoral / semiótica de la cultura / comunicación

\section{JAIR BOLSONARO'S X-RAY}

ABSTRACT. This paper aims to present the most representative singularities and irregularities of former candidate and current President Jair Bolsonaro in advertisement videos broadcasted during the 2018 presidential campaign, focusing on the use of body language. Using a qualitative methodology for analyzing images and videos inspired in concepts of semiotics of culture, it was possible to understand that body language is important during an election period, since it is a time when candidates are more sympathetic to people. This leads to the reduction of personal space boundaries, aggressive speeches and strange props that make up the semiosphere of the electoral campaign.

KEYWORDS: Jair Bolsonaro / body language / electoral body / semiotics of culture / communication 


\section{INTRODUÇÃO}

Inseridos no modelo democrático, os cidadãos estão habituados a participar no processo eleitoral, nomeadamente no processo de candidatura, propaganda eleitoral, votação e contagem. Embora nem todos os eleitores acreditem nesse comportamento, é possível fazer uma votação em determinado período e selecionar os candidatos que governarão o país (estados e municípios) em determinado período. Nas proximidades dessa data, as cidades se veem mergulhadas em jingles, panfletos, vídeos de divulgação, programas de televisão diversos - entrevistas, notícias, horário eleitoral gratuito e os bem conhecidos debates entre candidatos que disputam cargos executivos -, entre outros. Na fase de obtenção de votos, os candidatos costumam mudar suas atitudes e expressá-las em discursos voltados ao interesse do povo, frases bem elaboradas, sorrisos alegres, apertos de mão, acenos de mão e até mesmo confrontos ou brigas. Além disso, como parte da agenda dos presidenciáveis estão as viagens de campanha, em que o objetivo é levar sua mensagem, suas ideias, para convencer o cidadão de que ele é a melhor opção e, para isso, se submetem a muitas experiências, como vestir trajes típicos, distribuir e receber abraços, pegar crianças no colo, provar comida regional, aproximar-se do eleitor dentro de um espaço pessoal. São comportamentos que parecem buscar construir um sentido de "gente como a gente", ou seja, buscam criar identidade com o cidadão comum.

Porém, com o advento da tecnologia digital e a utilização das redes sociais como primeiro canal de comunicação, elas permitem que o público perceba diferentes aspectos dos candidatos, além de contar com outros canais de comunicação que até recentemente não eram utilizados. A mídia cumpre um papel importante nas eleições presidenciais pelo amplo alcance e poder de convencimento, mas, atualmente, as novas tecnologias de comunicação, principalmente as redes sociais, têm se mostrado muito relevantes. É preciso considerar ainda o contexto de disputa, fomentado pelas constantes pesquisas de opinião, como fator pujante nesses períodos, sendo capaz de direcionar o eleitor. São coeficientes que contribuem para a vitória. A mídia mais tradicional (jornal impresso, televisão e rádio) tem grande visibilidade, mas a presença das redes sociais e seu fácil acesso permite que outros públicos sejam atingidos e, consequentemente, amplia a retroalimentação. São espaços em que os candidatos precisam da mediação de empresas de comunicação, mas têm certa liberdade para produção e circulação de conteúdos, ou seja, eles (mais provavelmente os profissionais da área que empregam) são os produtores do próprio conteúdo, aparentemente tendo uma comunicação mais direta com seu possível eleitor.

A partir dessas exposições, consideramos que seria importante buscarmos uma abordagem acerca dos aspectos do corpo eleitoral através de conceitos da semiótica da cultura da última campanha eleitoral presidencial do Brasil. 0 último processo eleitoral contou com 13 candidatos, entre eles o ex-militar Jair Messias Bolsonaro, destacando-se pelas singularidades e irregularidades na expressão oral e gestos particulares durante 
a campanha eleitoral, que ainda mantém durante seu governo. Ao analisar textos audiovisuais da propaganda eleitoral veiculada na televisão e em vídeos no YouTube identificamos determinados traços do perfil físico do candidato. É um homem branco, alto (1,85 m aproximadamente), magro e de postura ereta. Cabelo liso castanho escuro com partes grisalhas nas laterais. Olhos azuis pequenos, nariz proeminente, rugas nas laterais dos olhos e na testa. Sua boca é muito pequena, com dentes uniformes, completos e levemente amarelados. Em determinadas entrevistas e vídeos de divulgação, percebe-se que a comunicação verbal do candidato se destaca pelo uso de palavras e frases simples e, às vezes, bastante informais. Um orador ousado e que gagueja de vez em quando, com fala célere, ofegante às vezes, com um vocabulário limitado e cheio de vícios de linguagem como "isso daí, "tá ok", "cangote" etc. Além disso, repete as palavras, intercala exaltação com fala apressada. Com um leve sotaque do interior de São Paulo, foi possível perceber que o presidenciável apresenta um leve problema de dicção (identificado por nós como anquiloglossia ou língua presa), podendo ser uma causa de natureza biológica, mas, mesmo assim, sua fala reflete naturalidade. Seu tom de voz é forte, semelhante ao tipo de fala militar ${ }^{1}$, como voz de comando, tanto uma causa de natureza biológica quanto, aparentemente, um recurso de oratória.

Destas exposições, consideramos que seria importante buscarmos uma abordagem acerca dos aspectos das corporalidades que permitam delinear os traços de feixes distintivos do candidato em textos audiovisuais veiculados em televisão e internet, atravessados, sobretudo, pela linguagem corporal na última campanha eleitoral brasileira, desde a perspectiva da Semiótica da Cultura (SC) podendo contribuir com a conexão entre a cultura e esse corpo eleitoral cambiante. 0 artigo se divide em três partes. Na primeira abordamos alguns conceitos da semiótica da cultura, como nexo entre a comunicação e linguagem corporal. No segundo ponto, tratamos o corpo, integrando os princípios de funcionamento da linguagem corporal com inspiração em Rosário (2019) nos textos audiovisuais mais representativos da campanha eleitoral. Na terceira parte, apresentamos o "DNA" do candidato, em que aspiramos a mostrar os gestos, expressões faciais e posturas mais representativas do ex-militar durante a campanha com base na SC. Por fim, apresentaremos algumas considerações sobre o que foi desenvolvido na análise.

\section{SEMIOSES DO CORPO POLÍTICO}

Entendemos que o candidato estudado ${ }^{2}$ diante da polêmica do processo eleitoral durante sua campanha à presidência da República teve uma atuação de acordo com as regras

1 A fala de um militar pode estar caracterizada por ter um volume alto, imposta, autoritária, de ordem, de disciplina.

2 Jair Messias Bolsonaro do ex-Partido Social Liberal (PSL). 
de conduta social e política dos espaços culturais em que se encontrava. Desta forma, visando organizar as dimensões de semioses que entrecruzam o político, o midiático e o corporal, estamos considerando o processo eleitoral como uma semiosfera que, através da criação e reprodução de textos, do uso de linguagens e de sistemas modelizantes, produz sentidos e significações inerentes ao ambiente político e cultural de cada país.

Lotman (1981, p. 46) indica que "a cultura pode representar-se como um conjunto de textos; mas do ponto de vista do investigador, é mais exato falar da cultura como mecanismo que cria um conjunto de textos e dos textos como realização da cultura". Trata-se de um complexo de "textos dentro de textos" que se constituem em linguagens e geram significação. Importante ressaltar que, para o autor russo, o conceito de texto é visto como uma unidade básica da cultura e não do sistema linguístico, o que permite que a cultura não só seja um armazenamento de informação, senão a reorganização contínua do texto e um modo de dar sentido ao mundo.

Rosário (2014, p. 170) entende a cultura, desde a perspectiva de Lotman, como "memória coletiva e mecanismo pensante envolvendo os eixos principais de seus estudos: semiosfera, sistemas, linguagens, códigos, codificação, memória, fronteiras, tradução". 0 autor refere-se à memória coletiva como uma memória longeva que recebe um aumento quantitativo de conhecimento através de diferentes textos, reorganização contínua por meio do sistema codificante e do esquecimento. Uma cultura se considera existente identificando-se com as normas aprendidas da própria memória e com a concorrência de textos de fora.

Segundo o entendimento de Machado (2003), a cultura seria semelhante a uma esfera delimitada, o que, ao mesmo tempo, obriga uma conexão com uma "não cultura", correspondendo a esse espaço diferente da cultura considerada, sabendo que existe, mas que é oposta ou alehia ao que se está acostumado. Nessa perspectiva, para compreender a cultura, é preciso lembrar que não a consideramos universal, mas sim representativa; não chegando a ser totalizante. Portanto, ela poderia ser referida como um sistema que tem uma organização interna específica de acordo com as territorialidades e temporalidades em que está inserida. Nela se constituem sistemas modelizantes, os quais são reguladores e tensionadores de textos diversos, formadores dos princípios e dos significados da própria cultura. Enfim, cultura é uma memória coletiva não hereditária. Machado a compreende como informação, dentro da perspectiva de regulação dos comportamentos. A autora indica que "uma vez que a cultura se compõe de traços distintivos, as informações vinculadas a uma coletividade configuram-se como um subconjunto caracterizado por um certo padrão de ordem" (Machado, 2003, p. 157). A compreensão da informação e a transmissão da mesma possuem uma função mais comprometida, pois, além de ser um modelo de regulação, combatem a tendência degenerativa da informação dentro de um sistema. 
Outro dos conceitos considerados é o de texto, entendido como a unidade mínima da cultura. Ele também é compreendido como um portador de sentido que reúne um conjunto de signos relacionados, compõe-se de uma ou mais linguagens - entendidas como um sistema de signos de uma mesma cultura - articulando sentidos possíveis para análise. Para Lotman (1996), o texto não só cumpre uma função de gerador de sentidos, como também é heterogênero e heteroestrutural ao poder manifestar-se com mais de uma linguagem. De acordo com Machado (2003, p. 168.), "o texto é um processo semiótico gerador de sentidos em processos interativos". Tal conjunto de signos organiza-se de determinada maneira, de acordo com os sistemas modelizantes, cuja função informativa será criar significados segundo o contexto.

Os textos podem ser modificados de acordo com a cultura, obtendo novos sentidos, isto é, reconfigurando-se. Por meio do contexto e da adaptação dos textos é que aparecem as irregularidades e regularidades, as previsibilidades e imprevisibilidades, as continuidades e descontinuidades do sistema semiótico.

O corpo, por si só, em suas manifestações comunicacionais pode ser visto como um texto. Nesse sentido, Campelo (1997, p. 10) observa que é possível "enxergar o corpo como texto, e o texto como mídia que se complexifica e se altera, se transforma com a história, porque é fruto de um diálogo com os outros textos, com o passado e sua memória". Dito isso, entende-se que o texto pertence a um modo de comunicar criado pela humanidade dentro de um determinado contexto, mas que pode ser reinventado no decorrer do tempo, gerando o processo de criação da semiose.

Outro dos conceitos da semiótica da cultura é a semiosfera. Vista como um espaço de realização da semiótica e da comunicação, é a área abstrata em que se manifesta o que é próprio da significação. Fora desse espaço não poderia acontecer uma linguagem, nem comunicação. Entende-se como o espaço-tempo em que "se organiza a complexa articulação de textos, linguagens, códigos, podendo ser entendida como uma dimensão na qual se manifesta o que é próprio da significação, da semiose" (Rosário, 2014, p. 174). Para Lotman, a separação entre núcleo e periferia parte da organização interna da semiosfera, é no centro que se concentrará o dominante, os elementos hegemônicos e os códigos mais aceitos. Vista também como um processo dinâmico, em que o núcleo é o espaço em que acontece o enriquecimento cultural, e a periferia como a região de maior atividade semiótica, em que "formam-se genes que se transformam, mudam e atualizam a memória da cultura" (Machado, 2007, p. 35). A partir do centro é que desenvolvemos nossas traduções, partindo de textos que modelizam nosso entorno por meio de uma hegemonia.

Em relação ao foco desse artigo, estamos acostumados a um certo perfil do candidato que atende determinadas regras, que se mantém dentro do núcleo da semiosfera eleitoral, mas se aparecer algum candidato tentando chegar ao poder com comportamentos, 
discursos, gestos ou posturas diferentes das regras, quebrará com o costumeiro, procedendo-se ao deslocamento da periferia para o centro.

A separação entre núcleo e periferia permite que exista uma organização dentro da semiosfera. "O papel da não homogeneidade do espaço semiótico forma reservas de processos dinâmicos e é uma maneira de criar novas informações" (Lotman, 1996, p. 30). Nos setores periféricos, o rigor da organização é menor e permite que esses processos dinâmicos encontrem menos resistências e se adaptem. Os textos que formam parte da periferia não são, necessariamente, estruturas fechadas, podem ser partes ou textos afastados, os quais são os mecanismos de reconstrução do sistema.

No interior da semiosfera circulam os códigos e sistemas modelizantes, estes definidos como um sistema determinado por regras combinadas por um grupo e que produz uma certa estruturalidade. Essas regras estabelecidas funcionam como uma metalinguagem universal de interpretação (Machado, 2003). Nos processos eleitorais da América do Sul, estamos acostumados a certas regras e costumes para organizar e permiter a comunicação e a persuasão dos eleitores. Alguns deles poderiam ser os debates, os vídeos políticos de campanha, as cores representativas do partido, os jingles, entre outros. Contudo, não se pode desprezar textos bem específicos que carregam suas singularidades e tensionam a semiosfera.

Os códigos são vistos como signos convencionais de caráter genérico, pelos quais é possível a constituição dos sistemas semióticos. (Machado, 2003). Lotman (1996) entende que o código corresponde à ideia de uma estrutura criada e de consenso imediato. Seria possível, então, denominá-lo como um conjunto de regras utilizado para atribuir significados a determinada linguagem. Assim, para Lotman (1978, p. 37), cada código específico desempenha duas funções, que estão acionadas, da comunicação e da modelização.

Para entender o conceito de modelização é necessário remontar ao pensamento do semioticista russo, que indica que a natureza e a cultura não poderiam ser consideradas como polos extremos a partir do momento em que atuam formando um modelo informativo. Para Machado (2003, p. 150), "modelização é a chave para compreender a produção de mensagens resultantes das relações entre as mais variadas linguagens ou os mais variados sistemas semióticos da comunicação social" e o "fim da modelização é alcançar um conhecimento sobre o mundo por meio de seus códigos" (Rosário, 2019, p. 6). Dito isso, pode-se entender que compreender os códigos resulta uma instrução por meio da qual, através da decodificação, conseguiremos nos entender socialmente.

\section{O CORPO EM LINGUAGENS}

No proceder da vida, os sujeitos recebem diversos estímulos da linguagem corporal que os fazem desenvolver textos corporais determinados, adotar outros e deixar de seguir 
alguns. Tudo partindo dos arranjos feitos pelos sistemas modelizantes da cultura, como também da personalidade de cada ser humano. Nesse ponto é bom lembrar que cada cultura apresenta um repertório próprio gestual, postural, de vestimentas, expressões faciais, etc. 0 corpo se configura a partir do que está fora do físico, mas que é incorporado (literalmente). 0 clima, a idade, a moda e a cultura são fatores que influenciam na escolha da vestimenta e dos adereços. De acordo com o evento social, a estação do ano, o gênero e estereótipos já estabelecidos pela sociedade; o ser humano cobrirá seu corpo com diferentes roupas, em que os tecidos em suas cores e texturas o permitirão estar dentro de determinado círculo social. Tal como indica Ferreira (1999, p. 130) "as pessoas compram para comunicar ideias aos outros e o corpo é peça prioritária nesse processo". Estamos constantemente seguindo padrões, tendências para ser aceito e formar parte de um grupo.

Dito isso, apresentamos o grupo de elementos que consideramos integrar para o funcionamento da linguagem corporal com inspiração em Rosário (2019) ${ }^{3}$, que o entende como feixes de traços distintivos da linguagem não verbal, que estarão presentes nos textos a serem analisados.

a. Expressões faciais: o rosto é, talvez, uma das partes do corpo mais comunicativas, já que é o centro das atenções no processo comunicativo comum por estar descoberto o tempo todo. Ele tem a capacidade especial para transmitir emoções e tem uma vasta série de possibilidades de coordenar os seus músculos: a testa, as sobrancelhas, os olhos, o nariz, a língua, os lábios em articulação geram diferentes textos que são codificados de acordo com o contexto. Trinta (1999, p. 120) indica que o rosto "delimita e determina áreas de uma expressão subjetiva possível", isto é, reflete o que poderíamos estar pensando, sendo um reflexo do mais interno do ser humano, revelando a personalidade da pessoa. A expressão facial permite também perceber a mudança das emoções, seja através do movimento de sobrancelhas, de olhos ou de lábios. Trata-se de um trabalho em conjunto que poderá revelar o sentimento da pessoa.

b. Gesto: geralmente acompanham as palavras, enfatizam os sentidos das frases e discursos verbais com o auxílio de expressões faciais, movimento das mãos, pernas e braços - o que não quer dizer que não existam gestos que significam sem o acompanhamento das palavras.

A cinésica está encarregada de estudar o movimento corporal do ser humano, e é um conceito desenvolvido por Ray L. Birdwhistell (Guiraud, 1991). Apresenta

3 Rosário apresenta na sua pesquisa Corpos em dissecação. A decodificação dos sentidos nas corporalidades, diversos traços distintivos, mas foram seletos apenas quatro, os quais estão mais vinculados ao trabalho e que estão diretamente relacionados com a linguagem do corpo. 
informação sobre o caráter, emoções e reações dos seres humanos em situações próximas. Esses gestos que acompanham a linguagem muitas vezes são involuntários, tensos, rápidos, repetitivos, mas tentar encaixar um gesto como universal ou como tendo um significado exclusivo é pouco recomendável, já que eles podem ter mais de um sentido.

c. Posturas: podem ser consideradas como uma atitude que uma pessoa adota frente a uma situação. Para Rosário (2019, p. 10), "as posturas se articulam numa combinação dos diversos membros do corpo, como cabeça, ombro, tórax, braços e pernas, mas se configuram principalmente pela posição da coluna".

0 corpo estabelece seus próprios limites através das posturas. Davis (1979) aponta que cada pessoa conta com um determinado número de posturas aprendidas, que constantemente são usadas e que até se tornam um signo característico do sujeito. Cabe indicar que o corpo também reagirá ante qualquer tipo de contato com o outro, dependendo da proximidade, da cultura, e o interesse do sujeito.

d. Vestimenta: Utilizada segundo o contexto, a vestimenta pode conotar diferentes significados, desde sedução, modernidade e antiguidade. Através da indumentária, o sujeito pode estimular respostas esperadas, como estabelecer o discurso de superioridade, de subjugação ou de beleza. A vestimenta pode distinguir nossa personalidade e de onde viemos. Pode ser que, mesmo sem participar de um grupo, decida-se vestir algumas roupas a fim de fazer ou sentirse parte de tal grupo, ou também simplesmente para expressar interesse. Tal como indica Villaça e Góes (1998, p. 109), “A moda se produz como arquivo e vitrine do ser/parecer, sugerindo comportamentos e atitudes, fabricando selfs performáticos". As peças podem ser paletós, camisetas, chapéus, calças, luvas, moletom, etc., mas os tecidos, comprimento e tamanhos poderão revelar ainda mais a identidade da pessoa e conotar significados.

\section{0 “DNA” DO MILITAR}

Para poder indicar as singularidades mais representativas do candidato consideramos uma observação de vídeos de divulgação, debates e notícias, destacando os traços com maior regularidade e que estejam fora do normativo. Para escolher os vídeos, precisamos revisar os canais de Youtube do candidato, analisar as repetições, bem como aqueles elementos da linguagem não verbal que se destacam nas sequências analisadas. Foram selecionados vídeos considerando-se três aspectos: maior tempo de exposição do candidato; enquadramentos e planos que permitam observar mais seus gestos, posturas e expressões; e, por fim, o figurino ou elemento que chamasse atenção no texto. 
Jair Bolsonaro destacou-se durante a campanha por diferentes eventualidades. Levar a facada em Minas Gerais, o gesto da arminha, a não participação no debate do segundo turno, foram alguns dos episódios que caracterizaram a campanha de 2018. Observar os textos em que o candidato participou, distinguir seus traços mais individuais, que provavelmente estão na periferia da semiosfera eleitoral de 2018 nos levou a considerar que são fatos atípicos durante uma campanha. Os gestos e posturas de Bolsonaro podem ser conectados aos de um militar, como a coluna ereta, ombros firmes, além da conhecida postura que vem da ordem "descansar" que consiste em separar os pés, levar os braços para trás e cruzá-los. Após revisar os textos, podemos destacar traços distintivos do candidato, começando pelo excesso de movimento das duas mãos enquanto fala. 0 outro movimento que faz com as mãos é fechar o dedo indicador com o polegar, movendo-o de cima para baixo, assim como o uso do dedo indicador num ângulo de cerca de 90 graus com o polegar, parecendo uma pistola.

0 uso das mãos pode ser interpretado como um reforço contundente do discurso verbal, demostrando segurança e autoridade. 0 candidato usa costumeiramente o dedo indicador em riste, muitas vezes apontando para a câmera e, portanto, reforçando a sua fala com os espectadores.
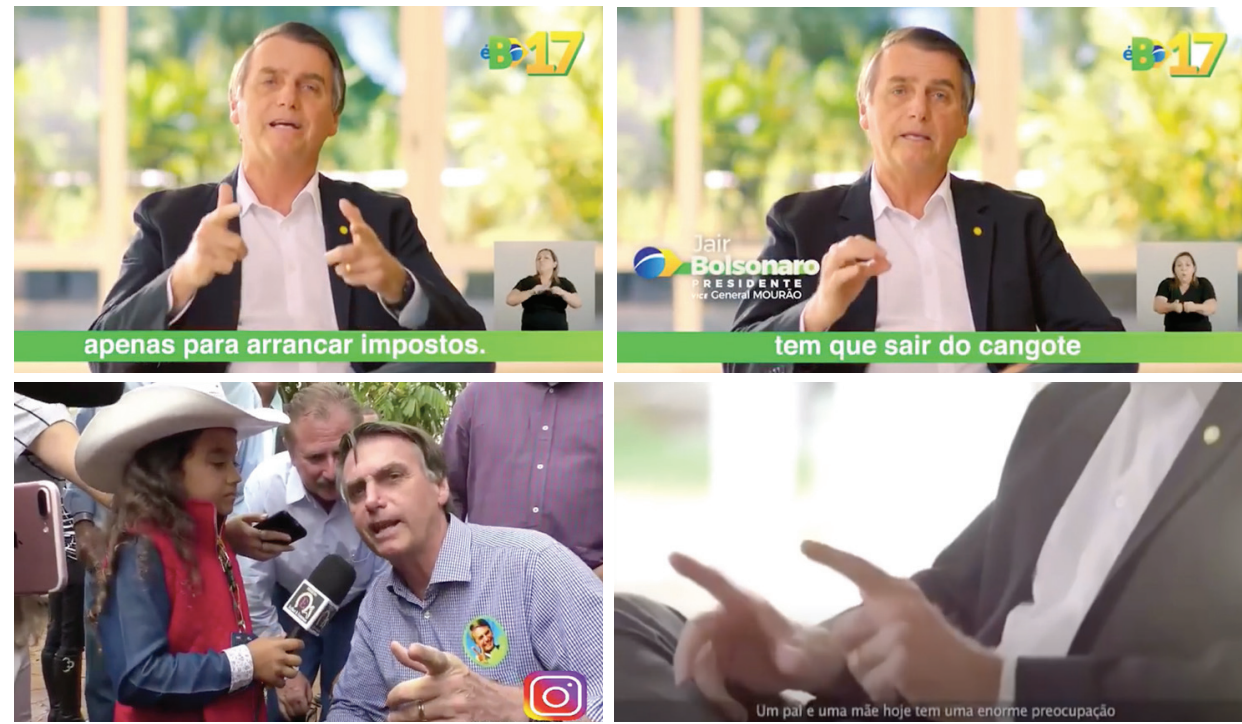

Figura 1. Gesto mais característico de Jair Bolsonaro

Fonte: Publicado pelo Canal Gabriela Pacheco (2020a) ${ }^{4}$.

4 Disponível em: https://www.youtube.com/playlist?list=PLME7SQfus0zoDDRL4Q4GznLqLiTXm AHdl Acesso em: 28 jan. 2021. 
É importante lembrar que o candidato foi criticado durante a pré-campanha por ensinar uma criança a fazer o gesto de arma com as mãos. Bolsonaro indicou que isso significava "coragem, patriotismo e honestidade" 5 , quando os sentidos costumeiros usados para esse gesto simbolizam uma arma e, portanto, podem denotar violência e conflitos $^{6}$. Tal gesto virou uma singularidade durante a campanha de Bolsonaro, sendo sua marca registrada até como presidente eleito, tendo em vista sua promessa de campanha da liberação do uso de armas para todos os cidadãos.

Mais de um dos vídeos de divulgação do candidato Bolsonaro conta com a presença de crianças, como é o vídeo "Com 8 anos de idade Esther mostra que o jornalismo tem futuro no Brasil". Nesse texto, ele muda a postura ereta para ficar agachado ao lado da menina, do mesmo tamanho dela e inclinando-se em sua direção. 0 olhar do candidato nesse vídeo está focado na menina Esther e na câmera. 0 espaço que separa os dois é inferior a uma distância pessoal ${ }^{7}$, estando, aproximadamente, a $20 \mathrm{~cm}$ um do outro. Com essas alterações de postura e uma expressão facial sorridente, ele se mostra muito simpático; mudando o tom de voz para mais brando e carinhoso, faz brincadeiras verbais com a criança sobre as perguntas que ela emite. Esse comportamento do candidato pode ser interpretado como paternal, no sentido de instigar empatia e credibilidade para com a criança em relação a ele (e de seus eleitores para com ele). Nesse viés, o então candidato parece ter domínio da linguagem verbal e não verbal das crianças.

Outro dos vídeos em que Bolsonaro rompe com o seu conhecido comportamento não verbal é "Depois de 4 homens uma menina mudou a sua vida", cuja temática é a reversão da vasectomia do candidato. A ruptura das regularidades se dá pelo registro do choro sentimental e embargado de Bolsonaro ligado à construção de um sentimento de afeto e alegria em relação a sua filha Laura, que nasceu após a reversão da vasectomia. A maior parte do audiovisual deixa o rosto do candidato em evidência e permite exibir seus olhos marejados e rosto um tanto avermelhado. Interessante que a abertura em fundo preto com a frase "Essa é uma história de verdade" e música melancólica já direcionam os sentidos que devem ser construídos sobre o depoimento de Bolsonaro e de sua expressão facial - é um vídeo em que só a cabeça importa. A emoção mostrada através das lágrimas também é realçada pela fala cortada por espaços de ausência de som. 0 final é coroado com a imagem de pai e filha (Laura) sorrindo para a câmera.

5 Disponívelem:https://oglobo.globo.com/brasil/bolsonaro-ensina-crianca-imitar-arma-com-mao22905093. Acesso em: 22 dez. 2020.

6 Para as crianças talvez possa ter os sentidos de uma brincadeira em que imitam mocinhos e bandidos que se digladiam com armas, mas, ainda assim, traz o significado de violência.

7 Lascani indica que Hall estuda a proxêmica e a definição dos espaços informais. Sendo um deles, a distância social como a área na qual a pessoa se sente confortável para comandar interações sociais com conhecidos e também estranhos. 
Uma regularidade nos vídeos de divulgação, quando o candidato aparece em meio ao público, é o fato de ser carregado nos ombros pela multidão ${ }^{8}$. Geralmente os candidatos são mostrados caminhando entre o eleitorado ou sobre um palco para ganhar maior visibilidade frente ao grande número de seguidores, sendo menos comum a postura de ser carregado por outras pessoas, a qual pode ser interpretada como reconhecimento por parte dos demais, estar acima do povo. Contudo, também torna o carregado bastante dependente do carregador, que é quem o mantém erguido.

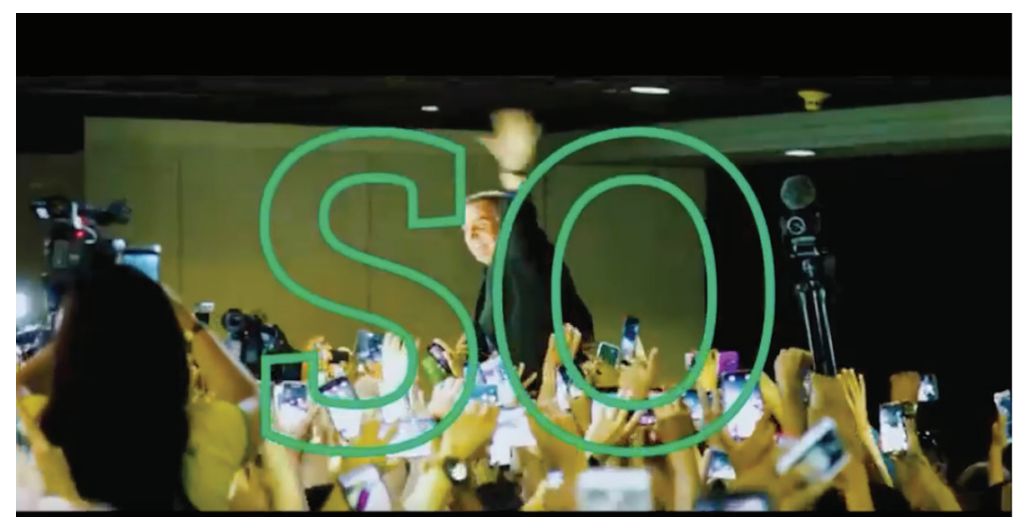

Figura 2. Jair Bolsonaro é carregado pelos fanáticos

Fonte: PSL (2019)9.

Sobre as expressões faciais do candidato, a mais representativa é o franzimento da testa, que pode ser observada com regularidade. Essa expressão pode ser entendida como um momento de desprezo, de seriedade, de preocupação. Para o franzimento da testa, os músculos se contraem entre as sobrancelhas, dando uma aparência tensa. Algumas vezes se observa que, ao franzir a testa, os músculos dos lábios refletem a expressão, baixando seu contorno.

8 Essa cena também se repetiu em muitas coberturas da campanha de Bolsonaro e, inclusive, no episódio em que ele recebeu a facada em Minas Gerais, em setembro de 2018. 0 candidato estava sendo carregado nas costas de outra pessoa até que foi surpreendido pela facada de Adelio Bispo de Oliveira.

9 Disponível em: https://www.youtube.com/watch?v=rcMkKA4RU7M\&list=PLME7SQfus0zoDDRL4Q 4GznLqLiTXmAHdl\&index=5 Acesso em: 28 de jan de 2021 


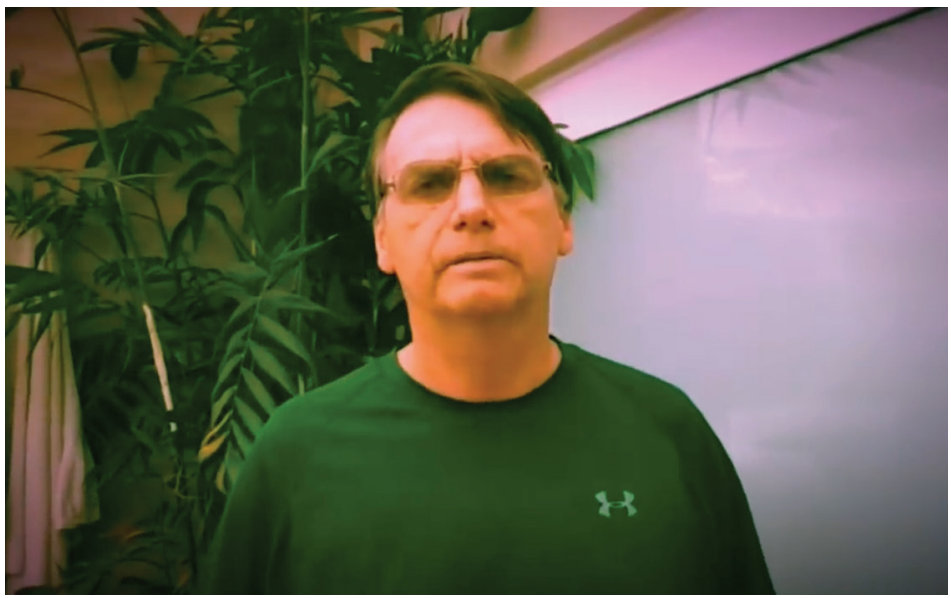

Figura 3. Jair Bolsonaro franzindo a testa

Fonte: Bolsonaro (2018b) ${ }^{10}$

0 candidato participou de dois debates durante a campanha eleitoral. 0 primeiro deles foi da Band, e teve uma participação de 21 minutos, enquanto no segundo debate, da Rede TV, contou com 12 minutos e 14 segundos de discurso. Conforme já esclarecido, ele não participou dos debates seguintes porque foi esfaqueado. Como gesto inusitado, durante o debate da Band, ele segura a cabeça com a mão, inclinando-se para frente, ao anotar pergunta de Álvaro Dias, fazendo lembrar a postura de um aluno com sono, ao qual a professora tende a chamar a atenção. 0 que mais rompeu com o esperado de um candidato foi ler anotações feitas nas mãos. Lembremos que no debate da Rede TV, no enfrentamento com a ex-candidata Marina Silva, o candidato levou uma 'cola' com os temas que devia abordar. Esse gesto quebra com o comportamento de um candidato presidencial. A ação constrói sentidos de uma atitude infantil ou de extrema informalidade, além, é claro, de falta de memória. Contudo, esse último sentido poderia ser ressignificado se o candidato levasse um pedaço de papel com as anotações. Da mesma forma, o político pareceu não mostrar muito compromisso com o cerimonial do evento.

10 Disponível em https://www.youtube.com/watch?v=F_v2auHWk8I\&list=PLME7SQfus0zoDDRL4Q4G znLqLiTXmAHdl\&index=3 Acesso em: 28 de jan de 2021 


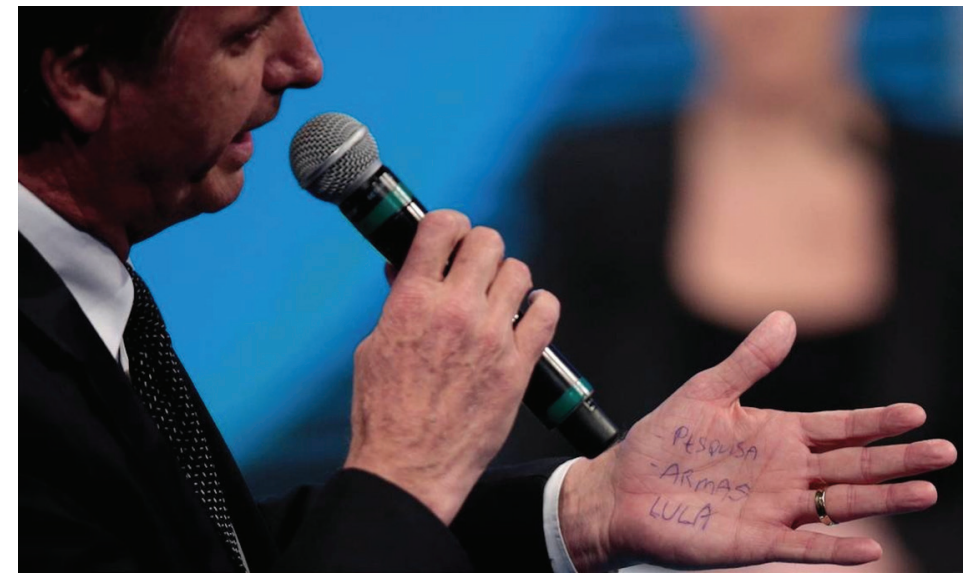

Figura 4. Bolsonaro escreve 'cola' na mão durante o debate da Rede TV Fonte: Jovem Pan (2018) ${ }^{11}$.

Também chamou atenção, como irregularidade, os poucos segundos em que Bolsonaro apareceu colocando a camisa para dentro das calças, em pé, durante o debate da Rede TV. A imagem foi cortada para outra com rapidez, mas ficou a mensagem de ação corporal inapropriada para um programa ao vivo.

Mesmo em um evento formal, ao vivo, o candidato não parece ter domínio da linguagem corporal apropriada para a televisão. Algumas das posturas do candidato evidenciam certo desconforto de participar de tal evento, como o excesso de movimentos do corpo, coçar o ouvido, levar a mão ao rosto. As principais singularidades são também irregularidades, como iniciar o debate sentado enquanto seus pares estavam de pé e ler anotações registradas nas mãos.

A vestimenta do candidato durante a campanha não apresentou regularidade, alternando de acordo com o tipo de vídeo de divulgação, mas é possível afirmar que ela oscila entre o informal e o formal. Nos vídeos de divulgação - estilo live, o candidato aparece com um look mais informal: uma camiseta com desenho militar, numa cor que mistura verde e marrom, uma camiseta esportiva da cor verde bandeira e camisa de mangas compridas em um xadrez miúdo preto e branco. Nos dois primeiros casos, destoa do que se viu nos vídeos de divulgação dos demais candidatos à presidência, rompendo com uma cerimonialidade do uso de camisa de mangas compridas, principalmente nos vídeos de depoimento.

11 Disponível em: https://jovempan.com.br/eleicoes-2018/presidenciais/bolsonaro-escreve-cola-na -mao-durante-debate-veja-o-que-estava-escrito.html. Acesso em: 28 jan. 2020. 
Cabe destacar que durante a campanha, Jair Bolsonaro destacou-se pela participação de vídeos nas redes sociais. Através da sua conta oficial, o candidato aproveita os benefícios da tecnologia, o livre espaço nas redes sociais e o tempo ilimitado para conversar com os internautas por meio de uma live no Facebook (todas as quintas-feiras às $20 \mathrm{~h}$ ) ou vídeos gravados com o telefone.

Assim como a vestimenta trouxe o sentido de informalidade, as produções audiovisuais mostraram uma realização bastante simples, pois parecem ter sido gravados com um celular, na casa de Bolsonaro, em plano sequência e com cortes crus. As imagens mostram o político mais descontraído na postura, com roupas esportivas e simples, cenário sem elaboração, mas o discurso verbal continua em tom incisivo e a expressão facial sisuda. Esses textos também abrem espaço para que o figurino, em conjunto com o cenário, traga um entendimento de que seu espaço privado pode ser penetrado, já que o candidato, aparentemente, abre as portas de sua residência e veste-se como se estivesse em casa.

Nesse sentido, cabe destacar que, após Bolsonaro ter sido eleito, virou uma singularidade do político o uso de vestimentas esportivas (camiseta, bermuda e chinelo) para aparecer em público em momentos não tão formais, como, por exemplo, aos finais de semana no Palácio da Alvorada. Também foi retratado, em época de pandemia, com a camiseta do Grêmio, comunicando o poder e faculdade de estar na rua sem proteção alguma em momentos de incerteza. Evidentemente, essas escolhas quebram com as normas sociais de um presidente que, pelo que se pode acompanhar, tem o hábito de receber seus ministros de chinelos e camiseta de time de futebol ${ }^{12}$ como também de um militar que despreza uma pandemia e a denomina "gripezinha" para priorizar a economia do país, em detrimento da integridade dos cidadãos.

\section{CONSIDERAÇÕES FINAIS}

Entendemos que as semiosferas eleitorais se configuram a partir de muitas similitudes no que concerne os sistemas modelizantes que orientam a linguagem corporal dos candidatos, o desempenho destes frente às câmeras, e mesmo os formatos audiovisuais que, na maioria dos casos, mantêm uma mesma configuração há alguns anos. Os vídeos de divulgação estão mais abertos para a novidade, uma vez que, em geral, são produzidos por agências de publicidade e marketing ou estruturas de comunicação que cuidam do conteúdo e funcionam como uma peça publicitária com diversas possibilidades de exibição que buscam, na maioria dos casos, valorizar o candidato. As estratégias são quase sempre as mesmas: o jingle, frases de efeito, imagens do candidato em meio ao

12 Disponível em: https://oglobo.globo.com/brasil/piadas-provocacoes-futebolisticas-em-reuniaoem-que-bolsonaro-aparece-de-chinelo-23457398. Acesso em: 12dez. 2020. 
público, sorrisos, abraços, promessas, pessoas do povo dizendo que votarão no político - a exceção fica por conta dos vídeos de divulgação tipo live, feitos em casa.

Jair Bolsonaro talvez tenha sido o candidato que esteve mais perto da periferia, naquele núcleo da semiosfera da campanha eleitoral, ao assumir posturas, gestos e expressões faciais diferentes do que se está acostumado. Já observamos que o candidato apresentou um discurso verbal com tom de voz mais agressivo, acompanhado de seu característico problema de diç̧ão. No aspecto corporal, o gesto com a mão que imita uma arma virou sua marca registrada. Seu desempenho frente às câmeras se caracterizou por um descompromisso com o que compõe o sistema modelizante do audiovisual eleitoral.

Dito isso, poderíamos indicar que uma linguagem corporal considerada adequada, que segue os códigos dominantes, que é hegemônica, não condiciona ganhar uma eleição. Todos sabemos que a vitória em uma eleição está atrelada a diversas linguagens, a numerosos contextos, a muitas estratégias, formando um todo de alta complexidade. Nesse sentido, a linguagem corporal é apenas um dos elementos que vai compondo esse todo e que tem especial importância na codificação da imagem do candidato. Seu modo de se mostrar, muitas vezes, é na sutileza, suas mensagens raramente 'gritam'; pelo contrário, na maioria das vezes, suas mensagens escapam.

Desde o aspecto semiótico, o presidenciável semiotiza a cultura e o sistema eleitoral em que estão inseridos, podendo indicar também os rumos contextuais da política no país. Fazem, portanto, menção à cultura de cada país, como também da política que o caracteriza segundo o contexto. É possível refletir sobre como tais textos estão falando da cultura. Isso pode ser visto através do comportamento do candidato, dos discursos verbais, das expressões corporais e das vestimentas dele. É evidente que esses textos se referem a uma parte da cultura brasileira, e que não representam o todo, mas informam sobre uma determinada congregação que comunica e que tem interferência sobre os sistemas semióticos e políticos do país.

Este artigo permitiu entender que, em época de campanha, a linguagem corporal, principalmente no aspecto das espacialidades, gestos, expressões faciais e vestimenta, é relevante. Esse é um tempo em que os candidatos são mais simpáticos, amigáveis e compreensivos frente aos eleitores, permitem que os limites espaciais sejam rompidos e toleram beijos, abraços, aglomeração, até mesmo troca de suores, assim como parecem escutar todos os problemas do público que o rodeia. Frente aos opositores são sérios, empertigados, mantém distância (no máximo um aperto de mãos). Invasão do espaço próprio, discursos agressivos, danças e adereços estranhos por vezes conformam a semiosfera da campanha eleitoral. 
É preciso afirmar que o corpo eleitoral faz parte desse corpo político. São versões que se constroem dependendo da personalidade do ator. Um candidato apresentará diferentes fachadas, mas a construção desse corpo não chega a ser totalmente falsa. É armado com base em uma singularidade desse candidato, que vai se moldando segundo os interesses que são criados para a persuasão da cidadania. Tal qual uma peça publicitária faz com seu produto, o corpo eleitoral é a melhor versão do político, aquela que tenta trazer o que ele tem de melhor, de mais comprometido com o cidadão, de mais sábio, de mais educado. Esse desempenho deriva de um corpo-texto camaleônico que, ao ser eleito, assume outras cores e texturas. Assim, deixa-se um questionamento, como provocação, para instigar futuras pesquisas: qual é o impacto que tem o corpo eleitoral.

\section{REFERÊNCIAS}

Bolsonaro, J. (26 de octubre de 2018). Chegamos na reta final. Vamos dar o último gás combatendo, COM A VERDADE, as mentiras do PT! [archivo de video]. https://www. youtube.com/watch?v=F_v2auHWk8I\&list=PLME7SQfus0zoDDRL4Q4GznLqLiT XmAHdl\&index $=3$

Campelo, C. (1997). Cal(e)doscorpos: um estudo semiótico do corpo e seus códigos. São Paulo: Annablume.

Davis, F. (1979) A comunicação não-verbal. São Paulo: Summus.

Fernandes, L. (20 de julio de 2018). Bolsonaro ensina criança a imitar arma com a mão. 0 Globo Brasil. Recuperado de https://oglobo.globo.com/brasil/bolsonaro-ensinacrianca-imitar-arma-com-mao-22905093

Ferreira, R. (1999). Corpo e Consumo: A Estética Carioca. Em Villaça, N.; Goes, F.; Kosovski, E. Que corpo é esse? (pp. 122-132) Novas Perspectivas.

Gamba, K. (15 de febrero de 2019). Piadas e provocações futebolísticas em reunião em que Bolsonaro aparece de chinelo. 0 Globo Brasil. Recuperado de https://oglobo. globo.com/brasil/piadas-provocacoes-futebolisticas-em-reuniao-em-quebolsonaro-aparece-de-chinelo-23457398

Guiraud, P. (1991). A linguagem do corpo (trad. L. Oliveira). São Paulo: Ática.

Jovem Pan (18 de agosto de 2018). Bolsonaro escreve 'cola' na mão durante debate; veja o que estava escrito. Jovem Pan. Recuperado de https://jovempan.com. br/eleicoes-2018/presidenciais/bolsonaro-escreve-cola-na-mao-durantedebate-veja-o-que-estava-escrito.html

Lascani, D. (15 de junio del 2020). Nova proxémica pós pandemia. Psicologia.pt. Recuperado de https://bit.ly/3dbCVFE 
Lotman, Y. (1978). Estética e semiótica do cinema. Lisboa: Editorial Estampa.

Lotman, Y. (1996). La semiosfera I. Semiótica de la cultura y del texto. Madrid: Ediciones Cátedra.

Lotman, Y.; Uspenski, I.; Ivanov, V. (1981). Ensaios de semiótica soviética. Lisboa: Livros Horizonte.

Machado, I. (2007) Semiótica da Cultura e Semiosfera. São Paulo: Annablume.

Machado, I. (2003). Escola de semiótica: a experiência de Tártu-Moscou para o estudo da cultura. São Paulo: Ateliê Editorial.

Menezes, A. (17 de setiembre de 2018). Bolsonaro se emociona ao falar da sua filha Laura [archivo de video]. Recuperado de https://www.youtube.com/watch $v=2 Y 3 k M \times 6 b 2 Q Y Z Z$

Partido Social Liberal PSL (16 de agosto de 2018). Muda, Brasil! Muda de verdade! - Clipe Oficial da campanha de Jair Bolsonaro para a Presidência. [archivo de video]. Recuperado de https://www.youtube.com/watch?v=rcMkKA4RU7M\&list=PLME 7SQfus0zoDDRL4Q4GznLqLiTXmAHdI\&index=5

Rosário, N. (2019). Aproximações da linguagem do corpo pela semiótica da cultura. 42 Congresso Brasileiro de Ciências da Comunicação. Intercom. Recuperado de http:// portalintercom.org.br/anais/nacional2019/resumos/R14-0276-1.pdf

Rosário, N.; Aguiar, L. (2014) Implosão midiática: corporalidades nas configurações de sentidos da linguagem. Significação: Revista de cultura audiovisual, 41(42) 166-185. https://doi.org/10.11606/issn.2316-7114.sig.2014.82572

Trinta, A. (1999). Face ao rosto (Subsídios a uma fenomenologia da aparência). En: Villaça, N., Goes, F., Kosovski, E. Que corpo é esse? (pp. 116-12). Novas Perspectivas. Villaça, N.; Goes, F. (1998). Em nome do corpo. Rio de Janeiro: Rocco.

Villaça, N.; Goes, F. (1998). Em nome do corpo. Rio de Janeiro: Rocco. 